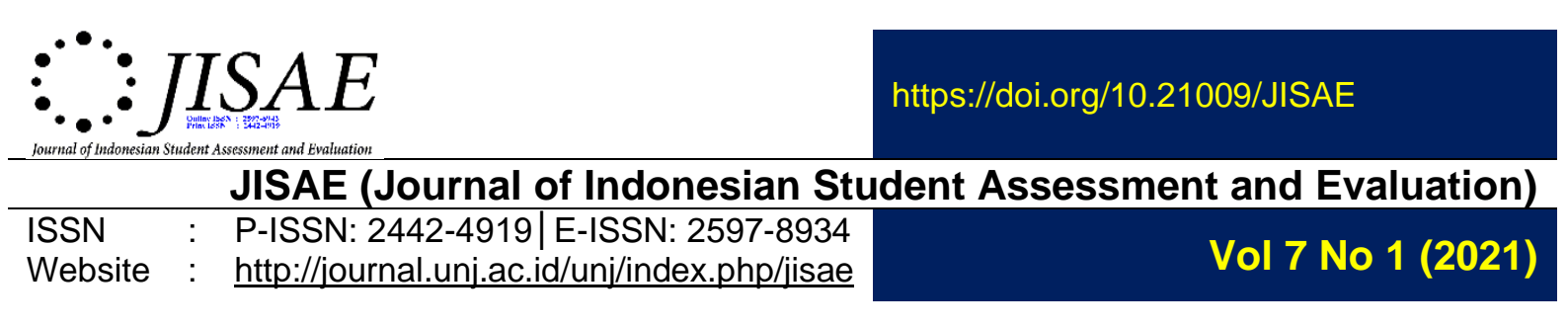

\title{
IMPLEMENTATION OF SELF-ASSESSMENT TO KNOW THE LEVEL OF STUDENT'S LEARNING MOTIVATION IN FOLLOWING ONLINE LEARNING
}

\author{
Fadilah Maharani ${ }^{1}$ \\ Bengkulu State Islamic Institute \\ Deta Heriani², \\ Bengkulu State Islamic Institute
}

Anisa Fitri ${ }^{3}$,
Bengkulu State Islamic Institute

Ahmad Walid ${ }^{4}$
${ }^{4}$ Bengkulu University

\footnotetext{
Address for Correspondence:

1fdlhrani@gmail.com,

${ }^{2}$ Annisafitri101@gmail.com,

33etaheriani@gmail.com,

4dongawalid19@gmail.com
}

\begin{abstract}
This study aims to determine the level of student learning motivation by applying self-assessment in participating in online learning, and to provide an objective description of how the student's learning motivation is. This research uses a quantitative approach with a survey method. The research was conducted at Bengkulu State Islamic Institute involving 40 students in the Natural Science Tadris study program. Data collection techniques in this study used survey techniques with a Likert scale. The survey is made on google form so that it is easily accessible to students. The data analysis technique used in this study is to calculate the percentage of data from each indicator, then interpret the data presentation score and analyze each indicator in depth. The results of this study indicate that the learning motivation of students of the Tadris Study Program of Natural Science of the Agam Islam Negeri Bengkuli Institute is good, it is obtained from the percentage score of the motivation which amounts to $78.83 \%$. This research is expected to be an evaluation of various parties in organizing online learning in tertiary institutions, especially those involving motivation.
\end{abstract}

Keywords: self assessment, motivation, online learning

\section{INTRODUCTION}

The development of information technology has a major influence on changes in every field. One of them is changes in the field of education. Technology can be used in teaching and learning activities, which can be said to be a change from conventional to modern (Handayani, 2020). Several studies show that technology has many positive effects on learning (Khusniyah and Hakim, 2019: 21). The internet has been integrated into a tool used to complement learning activities (Martins, 2015)

Coronavirus is a family of viruses that causes diseases ranging from mild to severe symptoms, the type of coronavirus is known to cause diseases that can cause severe symptoms such as Middle East Respiratory Syndrome (MERS) and Severe Acute Respiratory Syndrome (SARS) (Ministry of Health, 2020). Standard recommendations to prevent the spread of infection are washing hands regularly using soap and clean water, applying cough and sneezing etiquette, avoiding close contact with anyone showing symptoms of respiratory illness such as coughing and sneezing. Activities that involve groups of people are now starting to be limited, such as going to 
school, working, worshiping and so on. The government has appealed to work, study and worship from home to reduce the number of patients exposed to COVID-19.

Minister Nadiem Anwar Makarim issued Circular Number 3 of 2020 on the Education Unit and Number 36962 / MPK.A / HK / 2020 concerning the Implementation of Education in the Emergency Coronavirus Disease (COVID-19) so learning activities are carried out online in the context of prevention the spread of Coronavirus Disease (COVID-19) (Minister of Education, 2020). With online learning students have the flexibility to study time, and can study anytime and anywhere, students can interact with the teacher using several applications such as classroom, video converence, telephone or live chat, zoom or via the whats app group (Dewi, 2020.).

Online learning is often required to be more motivated because the learning environment usually relies on motivation and related characteristics of curiosity and self-regulation to involve the learning process (Selvi, 2010). motivation to learn is a behavior in achieving goals that are driven by stimulation or passion from within a person (Isnawati, Nina. Motivation is considered an important factor for successful learning, including in the online learning environment, so it is necessary to reconsider learning motivation in the learning support environment that uses technology) (Harandi, 2015).

Online learning is very well known among the public and academics with the term online learning (online learning). Another term that is very commonly known is learning distance (Pohan, 2020). Online learning is a distance education system with a set of teaching methods where there are teaching activities that are carried out separately from learning activities (Mustofa et al., 2019). Online learning provides benefits in helping to provide access to learning for everyone, thereby removing physical barriers as a factor for learning within the scope of the classroom, even if it is seen as something that is effective to be applied, especially in higher education (Riaz, 2018).

In his research, Faza mentioned several assessment models that can be applied in the distance learning process, including online-based assessments, portfolio assessments, and self-assessments. Self-assessment or self-assessment is an assessment method that gives students the opportunity to take responsibility for their own learning. Therefore, educators can start the self-assessment process by giving students the opportunity to validate their own thoughts (Ahmad, 2020). Selfassessment is one of the alternative methods of assessment in the form of a process where students simultaneously create and undergo evaluation procedures, assess achievement their own criteria, which match their own learning goals and expectations. (Hidayat, 2018).

This research was conducted. This study aims to determine the level of student learning motivation by implementing self-assessment in participating in online learning, and to provide an objective description of how the student's learning motivation is. The aspects examined in this study are related to aspects of 8 indicators of learning motivation, namely concentration, curiosity, enthusiasm, independence, readiness, enthusiasm or encouragement, never giving up, and self-confidence (Hamzah B. Uno, 2009).

\section{METHODS}

This research uses quantitative research. Quantitative research seeks to uncover universal truths and principles in the form of relationships between variables or phenomena (Nenty, 2009). While this type of research uses a survey method. 
Survey research is seen as a method to describe quantitatively specific aspects of a particular population so that data collection is carried out on a group of people whose results can be generalized back into a particular population (Pinsonneault \& Kraemer, 1993). The subjects of this study were 40 students of the natural science tadris study program at the Bengkulu State Islamic Institute, who took part in online learning.

The instrument used in this study used survey data. The survey is in the form of a questionnaire which is made on google form so that it is easily accessible to students. The survey that was made aimed to find out about student motivation in taking online learning, while the type of survey used a Likert scale. The Likert scale is used to measure attitudes, opinions, and perceptions of individuals or groups of people towards social phenomena (Sugiyono, 2018). The Likert scale table is presented below.

Table 1. Likert scale

\begin{tabular}{cc}
\hline Assessment criteria & Scoring scale \\
\hline Strongly agree & 5 \\
Agree & 4 \\
Fair / Neutral & 3 \\
Disagree & 2 \\
Strongly Disagree & 1 \\
\hline
\end{tabular}

Meanwhile, the data analysis technique in this study was carried out by calculating the percentage of the scores that have been obtained, while the formula for calculating the percentage is as follows.

Information :

$$
\% \text { Index formula }=\frac{T \times P n}{Y} \times 100
$$

T : The total number of respondents who voted

$\mathrm{Pn} \quad$ : Choice of Likert scores

Y : Ideal Score

The percentage results that have been obtained are interpreted by the scores based on the following interval table.

Table 2. Score Interpretation Criteria

\begin{tabular}{cc}
\hline Percentage & Information \\
\hline $0 \%-19.99 \%$ & Very Poor \\
$20 \%-39.99 \%$ & Not good \\
$40 \%-59.99 \%$ & Enough \\
$60 \%-79.99 \%$ & Good \\
$80 \%-100 \%$ & Very good
\end{tabular}

The results of the calculations above are the basis for analyzing in depth and concluding how the learning motivation of 5 th semester students of the natural science tadris study program at the Bengkulu State Islamic Institute in participating in online learning.

\section{RESULTS}

After conducting a survey of 40 students of the natural science tadris study program at the Bengkulu State Islamic Institute, with details of 3 male students and 37 female students. The suvery results are obtained which are described in the table below. 
Table 3. Survey Results of Student Motivation in Taking Online Learning

\begin{tabular}{|c|c|c|c|}
\hline Indicator & Aspect & Percentage & Criteria \\
\hline & $\begin{array}{l}\text { I always pay attention to the delivery of } \\
\text { competencies }\end{array}$ & $77.5 \%$ & Good \\
\hline & $\begin{array}{l}\text { I always understand the instructions } \\
\text { given by the lecturer }\end{array}$ & $77.5 \%$ & Good \\
\hline \multirow[t]{4}{*}{ Concentration } & $\begin{array}{l}\text { I always concentrate on teaching } \\
\text { materials and materials }\end{array}$ & $75.5 \%$ & Good \\
\hline & $\begin{array}{l}\text { I always listen carefully to every material } \\
\text { explanation that is conveyed }\end{array}$ & $78.5 \%$ & Good \\
\hline & $\begin{array}{l}\text { I always pay attention to lecturers' } \\
\text { delivery and explanation }\end{array}$ & $82 \%$ & $\begin{array}{l}\text { Very } \\
\text { good }\end{array}$ \\
\hline & $\begin{array}{l}\text { I always write down the material that is } \\
\text { delivered during the learning process }\end{array}$ & $71 \%$ & Good \\
\hline \multirow[t]{2}{*}{ Curiosity } & $\begin{array}{l}\text { I am always interested in the material } \\
\text { and materials conveyed }\end{array}$ & $70.5 \%$ & Good \\
\hline & $\begin{array}{l}\text { I often ask questions about the material } \\
\text { being taught }\end{array}$ & $68.5 \%$ & Good \\
\hline Spirit & $\begin{array}{l}\text { I am always passionate about conveying } \\
\text { ideas and opinions during learning }\end{array}$ & $74 \%$ & Good \\
\hline Independence & $\begin{array}{l}\text { I am able to answer or do well on the } \\
\text { assigned tasks }\end{array}$ & $80.5 \%$ & $\begin{array}{l}\text { Very } \\
\text { good }\end{array}$ \\
\hline Readiness & $\begin{array}{l}\text { I am always enthusiastic and ready to } \\
\text { answer or work on assigned } \\
\text { assignments }\end{array}$ & $68 \%$ & Good \\
\hline $\begin{array}{l}\text { Enthusiasm or } \\
\text { encouragement }\end{array}$ & $\begin{array}{l}\text { I have a desire to get the best score out } \\
\text { of every assignment }\end{array}$ & $94.5 \%$ & $\begin{array}{l}\text { Very } \\
\text { good }\end{array}$ \\
\hline Never give up & I always meant to do my job & $93 \%$ & $\begin{array}{l}\text { Very } \\
\text { good }\end{array}$ \\
\hline \multirow[t]{3}{*}{ Confidence } & $\begin{array}{l}\text { I am always confident in doing my } \\
\text { assignments }\end{array}$ & $83 \%$ & $\begin{array}{l}\text { Very } \\
\text { good }\end{array}$ \\
\hline & $\begin{array}{l}\text { I am very confident in the score that will } \\
\text { be obtained }\end{array}$ & $77 \%$ & Good \\
\hline & Average & $78.83 \%$ & Good \\
\hline
\end{tabular}

Students who have high learning motivation have a desire to get the best grades so that to achieve these goals students study well and diligently. From the table above shows that several aspects that are considered in seeing student concentration among 1) student attention to the delivery of competencies with a percentage of $77.5 \%$ are good criteria, because in the beginning of learning it is usually conveyed what competencies will be achieved, this percentage shows that students pay close attention to the competencies delivered in each subject to be taught, 2) understand the instructions given by the lecturer with a percentage score of $77.5 \%$ including good criteria, 3) concentration on materials and teaching materials with a percentage score of $75.5 \%$ including criteria good, This means that students have good concentration and focus on teaching material in learning activities. The ability of lecturers to prepare teaching materials and materials will help students understand the material to be delivered (Fitriyani et al, 2020). 4) listen well to every explanation of the material presented during the lesson with a percentage score of $78.5 \%$ including good criteria, 
this shows that not always the online learning process can run optimally, 5) pay attention to delivery and explanation with a percentage score of $82 \%$ including very good criteria, 6 ) recording the material delivered during the lesson with a percentage score of $71 \%$ including good criteria, recording the material presented will help students understand and remember the material that has been studied.

The second indicator related to learning motivation is student curiosity. The aspects studied were 1) interest in the material and material presented with a percentage score of $70.5 \%$ with good criteria, and 2) asking questions about the material presented with a presentation score of $68.5 \%$ with good criteria, so that it means that students have courage in asking questions so as to create active learning and reciprocal learning, namely two-way learning and not just one-way learning.

The third indicator is related to enthusiasm for learning, motivation and enthusiasm for learning which have a very important relationship in learning activities, this shows that both lecturers and students must show high enthusiasm for learning.each learning activity (Fitriyani et al, 2020). The aspects studied are related to the enthusiasm in conveying ideas and opinions during learning with a percentage score of $74 \%$ with good criteria so that it means that students are brave in expressing opinions, ideas and ideas even though through online learning.

Indicator the fourth is related to independence, independent learning is learning that is carried out by students with little or no help from outside parties, students are responsible for making decisions related to their learning process and have the ability to carry out the decisions they make (Endang, 2014). The aspect that is observed in independence is being able to answer or do the assignments well with a percentage score of $80.5 \%$, this shows that students have excellent guidance in completing assignments given by the lecturer.

The fifth indicator is related to student readiness, while the observed aspects are enthusiasm and ready to answer or do assignments given with a percentage score of $68 \%$, this means that students have good readiness and enthusiasm in doing the assigned assignments.

The sixth indicator is related to enthusiasm and encouragement, the aspect studied is the desire to get the best score from each task with a percentage score of $94.5 \%$ with very good criteria, this indicates that students have a very strong enthusiasm or motivation to get the best score from the assignment. given by the lecturer in each learning process.

The seventh indicator is related to never giving up in learning, never giving up is the main key for every student to get the best score, the aspect studied is being serious in doing the assignment with a percentage score of $93 \%$ with very good criteria, this shows that students are very serious in doing the assignment given by the lecturer and having a very high unyielding attitude to get the best score.

The last or eight indicator is self-confidence, the aspects studied include 1) confidence in doing assignments with a percentage score of $83 \%$ with good criteria, this shows that students have high self-confidence or are very good at doing assignments given by the lecturer 2) confident in the score obtained with a percentage score of $77 \%$ with good criteria so that it means that students have good selfconfidence with the score or results that will be obtained from the task that has been done.

Based on the results of the analysis of student motivation towards online learning obtained from the table above, it shows that the average overall percentage score is $78.83 \%$ in a good category, so it can be interpreted that students of the Natural Science Inatitut Bengkulu State Islamic Studies study program have good motivation 
to follow. online learning. The period of the Covid-19 pandemic did not hinder student motivation to carry out learning activities online.

\section{CONCLUSION}

Based on the results of data analysis previously described, it can be concluded that From the observed aspect, student learning motivation shows an average score of $78.83 \%$ including good criteria, it can be said that in participating in online learning students have good motivation, although in practice there are deficiencies found due to covid-19, but not There are other options besides optimizing online learning, because technology is the only bridge in transferring knowledge from student lecturers. This research is expected to be an evaluation of various parties in organizing online learning in tertiary institutions, especially those involving motivation.

\section{REFERENCES}

Ahmad, lqbal Faza. (2020). Alternative Assessment in Distance Learning in the Emergency of Coronavirus Disease (Covid-19) in Indonesia.Journal of Education. Volume 7 pages 195-222

Astutik, S., and Maryani. 2007. Learning Assessment Module. Jember: University of Jember

Dewi, WAF2020. The Impact of Covid-19 on the Implementation of Online Learning in Primary Schools. Journal of Educational Sciences Volume2nomor 1 Halm 556

Endang Mulyatiningsih, Indart I (2014). The Influence of Family Social Interaction, Learning Motivation, and Learning Independence on Learning Achievement The Influence Of Social Interaction Of Family Relations. Journal of Education and Culture, Vol. 20, Number 4

Fitriyani, Yani, Irfan Fauzi, Dan Mia. (2020). Zultrianti Sari..Motivating Student Learning in Online Learning During the Covid-19 Pandemic. Journal of Research Results and Literature Review. Vol. 6, No.2, 165-175

Hamzah B. Uno. (2009). Motivation Theory And Its Measurement Analysis In The Field Of Education. Jakarta: Earth Literacy.

Handayani, octafia ika and Siti Sri Wulandari. 2020. Online Learning as a Study From Home (SFH) Effort During the Covid Pandemic 19. Journal of Office Administration Education (JPAP). Volume 8, Number 3

Harandi, SR (2015). Effects Of E-Learning On Students' Motivation. Procedia-Social Andbehavioral Sciences, 181, 423-430.

Hidayat, Adityawarman. META ANALYSIS: THE IMPORTANCE OF SELF AND PEER ASSESSMENT IN LEARNING Basicedu Journal Volume 2 Number 1 Year 2018 Pages 95-101 JOURNAL BASICEDU

Ministry of Health RI. 2020. Guidelines for the Prevention and Control of Coronavirus Disesase (Covid-19)

Kusniyah \& Hakim, L. (2019). Effectiveness of Online-Based Learning: An Evidence on English Language Learning. Journal of Educational Research and Thinking, Vol. 17 No.1

Martins, M. De L. (2015). How To Effectively Integrate Technology In The Foreign Language Classroom For Learning And Collaboration. Procedia -Social And Behavioral Sciences. Vol. 174, pp. 77-84

Minister of Education. (2020). Circular Number 3 of 2020 concerning the Implementation of Education in a Coronavirus Emergency (COVID-19). 
Mustofa, MI, Chodzirin, M., Sayekti, L., \& Fauzan, R. (2019). Formulation of Online Lecture Models as Efforts to Suppress Disparities in Higher Education Quality. Walisongo Journal Of Information Technology, 1 (2), 151. https://doi.Org/10.21580/Wjit.2019.1.2.4067.

Nenty, HJ (2009). Writing A Quantitative Research Thesis. International Journal Of Educational Sciences, 19 (1), 32.Https://Doi.Org/10.1080/09751122.2009.11889972

Pinsonneault, A., \& Kraemer, KL (1993). Survey Research Methodology In Management Information Systems: An Assessment. California Digital Library University

California.Https://Escholarship.Org/Content/Qt6cs4s5f0/Qt6cs4s5f0.Pdf.

Pohan, AE2020. Online Learning Concept Based on a Scientific Approach. Central Java. CV Sarnu Unutung

Riaz, A. (2018). Effects Of Online Education On Encoding And Decoding Process Of Students and Teachers. International Conference E-Learning, 42-48. Https: //Files.Eric.Ed.Gov/Fulltext/ED590288.Pdf.

Sugiyono. (2018) Quantitative, Qualitative and R \& D Research Methods. Bandung: Cvalfabeta.

Selvi, K. (2010). Motivating Factors In Online Courses.Procedia-Social And Behavioralsciences, 2 (2), 819-824. 